\title{
Edukasi Pentingnya Vaksinasi dan Protokol Kesehatan 5M dalam Menghadapi COVID-19 pada Jemaat Waai
}

\author{
Margaretha M. A. Apituley*, Febryanti Sariwating, Aprilia F Telussa, Stephany B. Sopacua, \\ Helenna M Tahitu,Wenly Lekahena, Mansye Ruhulesin, Megawatty Wuarlela, Adventia \\ Liklikwatil, \& Jelly V.D.Tahitu
}

Universitas Kristen Indonesia Maluku, Indonesia

\begin{abstract}
Virus Corona atau severe acute respiratory syndrome coronavirus 2 (SARS-CoV-2) adalah virus yang menyerang sistem pernapasan. Penyakit karena infeksi virus ini disebut COVID-19. Infeksi virus Corona disebut COVID-19 (Corona Virus Disease 2019) dan pertamakali ditemukan di kota Wuhan, China pada akhir Desember 2019. Virus ini menular dengan sangat cepat dan telah menyebar ke hampir semua Negara termasuk Indonesia, hanya dalam waktu beberapa bulan. Di Indonesia masuk pada awal Maret 2020. Dengan adanya virus corona ini pemerintah mengambil banyak tindakan salah satunya adalah Vaksinasi untuk mencegah atau meminimalisir penularan COVID 19 khususnya di Indonesia, namun yang menjadi masalahnya adalah banyak masayarakat yang masih acuh tahu dengan Vaksinasi ataupun dengan Protokol kesehatan 5M. Untuk membantu upaya pemerintah dalam mengahadapi masalah ini maka, Mahasiswa KKN Universitas Kristen Indonesia Maluku Fakultas Theologi Angkatan 2021 akan melakukan program-program guna mengedukasi masyarakat akan pentingnya Vaksinasi dan Protokol Kesehatan 5 M dalam menghadapi Virus Corona, selain itu Kegiatan KKN ini juga mengangkat masalah sampah yang terjadi di jemaat focus kelompok. Kegiatan dilakukan secara berkelompok dan dibimbing oleh instruktur KKN secara online. Setiap program akan dilakukan baik secara online maupun offline dengan penerapan protokol Kesehatan, program-program tersebut antara lain, sosialisasi vaksinasi dan protokol kesehatan 5M, Pembagian Masker dan Pembuatan Video Kreatif Vaksinasi dan beberapa kegiata lainnya sebagai pendukung. Semua kegiatan ini diharapkan untuk membantu dan membangun kesadaran Masyarakat untuk dapat mencegah Virus Corona ataupu menyelesaikan msalah yang ada dalam jemaat Waai. Kegiatan kelompok akan di khususkan pada jemaat Waai Kecamatan Salahutu, Kabupaten Maluku Tengah.
\end{abstract}

Keywords: Sosialisasi vaksinasi, COVID-19, Edukasi.

\section{Introduction}

Virus Corona atau severe acute respiratory syndrome coronavirus 2 (SARS-CoV-2) adalah virus yang menyerang sistem pernapasan. Penyakit karena infeksi virus ini disebut COVID-19. Virus Corona bisa menyebabkan gangguan ringan pada sistem pernapasan, infeksi paru-paru yang berat, hingga kematian.

Severe acute respiratory syndrome coronavirus 2 (SARS-CoV-2) yang lebih dikenal dengan nama virus Corona adalah jenis baru dari coronavirus yang menular ke manusia. Virus ini bisa menyerang siapa saja, seperti lansia (golongan usia lanjut), orang dewasa, anak-anak, dan bayi, termasuk ibu hamil dan ibu menyusui.Infeksi virus Corona disebut COVID-19 (Corona Virus Disease 2019) dan pertama kali ditemukan di kota Wuhan, China

\footnotetext{
* Corresponding author:

E-mail address: margarethaapituley@gmail.com
} 
pada akhir Desember 2019 (Ahmar \& Eva, 2020). Virus ini menular dengan sangat cepat dan telah menyebar ke hampir semua negara, termasuk Indonesia, hanya dalam waktu beberapa bulan (Pane, 2021).

KKN di masa Pandemik COVID - 19 bukanlah hal yang mudah. Dilansir dari media masa online, COVID-19 telah ada di Indonesia sejak awal 02 Maret 2020 dan masih terus mewabah hingga sekarang (Ellyvon, 2021). Sebab situasi ini membatasi ruang gerak semua pihak, baik mahasiswa $\mathrm{KKN}$, tetapi juga masyarakat yang diharapkan untuk memiliki peranan aktif dalam memikirkan, merancang dan menyelesaikan masalah-masalah yang mereka hadapi secara bersama-sama. Meskipun demikian adanya, keterbatasan ruang gerak ini dan partisipasi masyarakat yang mungkin tidak bisa dilakukan secara maksimal tidak boleh membuat hilangnya ide-ide kreatif untuk menolong dan mentranformasi kehidupan mereka. Justru bagi kami, pengalaman ber-KKN di masa pandemik ini menjadi ruang belajar yang real untuk mengasah kemampuan intelektual dan lainnya demi merancang kegiatan-kegiatan yang konstruktif serta kontekstual.

Dari sejumlah mahasiswa Universitas Kristen Indonesia Maluku Fakultas Teologi yang melakukan KKN pada semester genap Tahun Akademik 2020-2021 ini, kami ditempatkan di Klasis Pulau Ambon Timur (KPAT) sejak 5 Juli 2021 - 16 Agustus 2021. Berkaitan dengan kegiatan KKN ini maka kelompok kami telah mencari sejumlah masalah yanga ada Di Klasis Pulau Ambon Timur kami pun mengambil 2 masalah utama yaitu kurangnya kesadaran Vaksin dan Penerapan Prokes 5M ditengah Masyarakat dan, kuranya kesadaran akan sampah plastik.dua hal ini menjadi tujuan KKN yang akan dilakukan kelompok di Jemaat Waai. Jemaat Waai sendiri terletak di Negeri Waai, Kecamatan Salahutu, Kabupaten Maluku Tengah. Jemaat ini berbatasan di sebelah utara dengan Negeri Liang; Selatan dengan Negeri Tulehu, Timur dengan Selat Haruku; dan Barat dengan Negeri Morela.Waai dipilih karena beberapa pertimbangan khusus dari kelompok dan instruktur. Diantaranya karena masyarakat di jemaat Waai masih kurang memahami tentang Vaksinasi dan Mematuhi Protkes 5M dan juga kurangnya kesadaran mereka tentang sampah Plastik

\section{Permasalahan Prioritas Mitra}

Berdasarkan latarbelakang konteks yang telah di deskripsikan diatas maka, yang menjadi prioritasi kegiatan KKN kelompok kami adalah: 1) bagaimana membangun kesadaran AM GPM Jemaat GPM Waai terhadap pentingnya penerapan protokoler kesehatan dan melakukan vaksinasi COVID-19 di masa pandemic, 2) membangun kesadaran untuk peduli terhadap sampah plastik khusnya, Ada beberapa hal mendasar yang membuat kelompok memilih mengakat masalah ini :

1) Data dari Puskesmas Waai pada tanggal 31 Juli 2021 menunjukkan bahwa ada 9 pasien yang terkonfirmasi COVID-19 yang berasal dari Waai dan berdomisili di negeri ini pula (Puskesmas Waai, 2021). Namun menariknya banyak anggota masyarakat Waai yang tidak menjalankan protokoler kesehatan dengan baik dan juga tidak mau divaksin dengan berbagai alasan yang variative, antara lain: 1). Sebagian besar masyarakatnya tidak percaya akan keberadaan COVID-19; 2). Keyakinan bahwa di Waai tidak ada pasien terkonfirmasi COVID-19; 3). Percaya bahwa virus COVID-19 itu juga tidak ada; 4). Terpengaruh oleh informasi hoax yang beredar di media social secara tidak tertanggung jawab. Hal ini akhirnya juga berdampak pada kesadaran mereka untuk divaksin dan dalam kegiatan-kegiatan ibadah yang dilakukan tanpa penerapan prokes yang ketat.

2) Dari hasil pengamatan Kelompok ditemukan bahwa di jemat Waai banyak sekali sampah yang menumpuk di pantai-pantai. Yang dimana sampah-sampah itu dapat membuat masyarakat sakit dikarenakan kondisi lingkungan yang kurang sehat itu. Jika kondisi imun masyarakat menurun sebagai akibat dari kurang optimalnya penanganan sampah maka kemungkinan imun yang lemah itu juga dapat mempercepat terjadinya penularan virus-virus yang berbahaya. Apalagi tidak tersedianya tempat pembuangan sampah khusus yang disediakan oleh pemerintah dan selama ini masyarakat menggunakan tepi pantai, tepi sungai, daerah lembah (alor) dan hutan sebagai tempat pembuangan sampah baik yang bersifat organik maupun anorganik. Oleh sebab itu diperlukan peningkatan kesadaran masyarakat terhadap bahaya sampah.

3) Banyak anak-anak muda yang tidak taat dengan protokol kesehatan bahkan banyak yang belum vaksin dari data Puskesmas pada 31 july 2021 yang di dapat dari puskesamas Waai sebanyak 240 itu data secara 
keseluruhan .[3] Kelompok memiliki tujuan agar melalui angkatan muda sebagai tongkat estafet agar bisa memotivasi jemaatnya menyadari pentingnya vaksinasi dan menerapkan protokol kesehatan.

4) Masalah prioritas yang kelompok tentukan ini sejalan atau sesuai dengan tugas dan tujuan KKN yang diterapkan di tengah masa pandemik. Dengan cara ini, kami merasa terlibat mendukung pemerintah dan memelihara kehidupan yang merupakan Anugerah Tuhan dan harus dijaga secara bersama oleh semua orang.

\section{Solusi Permasalahan}

Terhadap realitas diatas maka menurut hasil percakapan atau koordinasi dengan para mitra di Jemaat GPM Waai dan di Negeri Waai, maka kami bersama-sama memutuskan untuk membangun kesadaran para pemuda melalui beberapa kegiatan mendasar yaitu:

1) Sosialisai. Didalamnya kelompok berupaya untuk memberikan pemahaman tentang bahaya COVID-19, pentingnya prokes 5M dan vaksinasi. Kegiatan ini dilakukan secara daring atau melalui media Zoom.

2) Melakukan kegiatan seperti pemungutan sampah di lokasi-lokasi yang tercemar sampah dan dapat menggangu kesehatan masyarakat. Kelompok membuat kegiatan ini mempunyai beberapa alasan terkhususnya untuk membantu meningkatakan imun tubuh jemaat di Waai, karena ketika lingkungan kotor akan sangat berpengaharuh terhadap kesehatan juga turunnya imun tubuh dan virus corona akan mudah terjangkit.kemudian untuk menindak lanjuti hal ini kelompok juga melakukan 3 kegiatan tambahan agar tujuan kegiatan ini terlaksana antara lain penyuluhan sampah, pembuatan video edukatif,dan pemberian tempat sampah kepada jemaat

3) Pemberian masker kegiatan ini sebagai bentuk gerakan awal kelompok yang ditujukan untuk mendukung dan membangn kesadaran menerapkan Protokol Kesehatan 5M, meskipun tidak banyak namun diharapkan dapat memberikan dampak positif bagai Jemaat Waai.

4) Dan pembuatan video edukatif kreatif dan inovatif untuk membangun kesadaran mereka. Kegiatan ini dimaksudkan untuk memberikan edukasi melalui media sosial, melihat masa sekarang ini orang lebih banyak menggunakan waktu mereka untuk media sosial dari pada didunia nyata sehingga kelompok berpikir bahwa lebih efektif menggunakan video dan kemudian disebarkan dalam media sosial daripada sekedar membuat poster atau spanduk yang kemudian akan rusak dan hilang.

Semua kegiatan ini dilakukan dengan mitra khusus AMGPM Cabang damai dengan ketujuh ranting yang ada didalamnya dan sekitar 2.233 jiwa (Tim Renstra, 2020). Pilihan kami untuk bermitra dengan AMGPM karena: 1). Pemuda memiliki dinamika yang tinggi meskipun ditengah pandemik. Artinya, mereka bisa menjadi pihak yang membawa virus COVID-19 bagi keluarga dan masyarakat jika mereka tidak memahami COVID-19 dan upaya-upaya pencegahannya seperti sekarang. 2). Pemuda juga adalah agen perubahan didalam jemaat dan masyarakat. Bekerja sama dengan pemuda akan memberi ruang dan peluang untuk membangun kesadaran bersama dalam masyarakat baik akan pentingnya menjalankan prokes 5M, vaksin COVID-19, maupun membuang sampah pada tempatnya. Dan juga sebagai tongkat estafet meneruskan edukasi kepada orang-orang disekitarnya.

\section{Metode Pelaksanaan}

Tahap Persiapan

- Pembicaran dengan mitra-mitra terkait kegiatan yang akan dilakukan

- Mengadakan pertemuan dengan Instruktur Kelompok untuk melihat apa saja yang dibutuhkan selama kegiatan, serta menentukan waktu dan tempat kegiatan.

- Kelompok mempersiapkan segala sesuatu yang berkaitan dengan narasumber maupun fasilitas pendukung kegiatan

Tahap Pelaksanaan

- Sosialisasi dilakukan satu kali dengan melibatkan Angakatn Muda cabang Damai dengan narasumber Dekan Fakulltas Kesehatan UKIM dan difasilitasi oleh mahasiswa KKK dan dilakukan secara daring melalui media Zoom dengan 100 partisipan,didalamnya disebarkan Google Form untuk melihat luaran peserta. 
- Pembagian Masker dilakukan 2 kali, yang pertama diberikan kepada gereja dan yang kedua deberikan kepada anak-anak sekolah minggu, total diberikan sebanyak 22 pack, dewasa 15 pack dan anak-anak 7 pack. Pembagian masker dilakukan secara simbolis sebagai bentuk kepedulian kelompok

- Kerja bakti dilakukan satu kali berlokasi di pantai jalan pica jemaat Waai dengan melibatkan Angakatan Muda dan Tim Kalesang Waai dan Mahasiswa KKN kelompok 8.

- Penyuluhan Sampah dilakukan satu kali degan melibatkan AM Jemaat Waai dengan 2 narasumber antara lain Ketuan Beta Bank Sampah Dan Ketua Kalesang Negri Waai.Penyuluhan sampah ini dilakukan sebagai program lain menindak lanjuti program kerja bakti yang telah terjadi sebelumnya.

- Pembuatan Video Kreativ, dilakukan 2 kali yang pertama untuk video prokes dan vaksinasi dan kedua untuk peduli samah dengan mahasiawa KKN sebagai pembuat dan disusun juga oleh Mahasiswa KKN.

Tahapan evaluasi

- Evalusi kegiatan dilakukan dengan melihat kembali google form untuk mengukur seberapa besar dampak dari sosialisasi dan penyuluham yang di lakukan

- Sedangkan untuk kegiatan yang lain evalusi dilakukan dengan pengamatam dan evalusi dengan instruktur

\section{Hasil dan Luaran yang Dicapai}

\section{- $\quad$ Sosialisasi Kesadaran Vaksisnasi Dan Protokol kesehatan}

Sosialisasi kesadaran vaksinsasi dilakukan secara daring dan menjadi langkah awal dari tujuan kelompok memberikan edukasi yang membangun kesadaran bagi Jemaaat Waai Khususnya AM Damai Waai, yang dilakukan tanggal 3 Agustus 2021 jam 14:00-16:00 WIT dengan Narasumber Dosen Fakultas Kesehatan dan difasiliatsi oleh Mahasiwa KKN . Namun dari 2,233 jiwa AM yang hadir hanya sekitar 15 orang dari 7 ranting yang ada. setelah melakukan pengamatan dengan situasi dan perbincangan dengan beberapa Anggota AM maka ada beberapa hal yang membuat mereka tidak dapat mengikuti zoom antara lain: sinyal yang kurang stabil, tidak semua memiliki hp Android, ada kesibukan masing-masing yang tidak bisa ditinggalkan, dan juga kurannya rasa antusiasme terhadap sosialisasi seperti ini.

Dalam sosialisi ini juga disebarkan google form pada awal dan akhir kegiatan untuk mengukur pengetahuan dari partisipan. Dari 100 peserta yang ditargetkan hanya 15 yang hadir $=15 \%$. Dari 15 orang yang mengisi Google form mereka menyatakan bahwa mau untuk di vaksi dan menerapka prokes $5 \mathrm{M}$ hal ini menunjukan bahwa dari target luaran yag di tentukan kelompok maka hanya $15 \%$ yang berhasil terpenuhi.
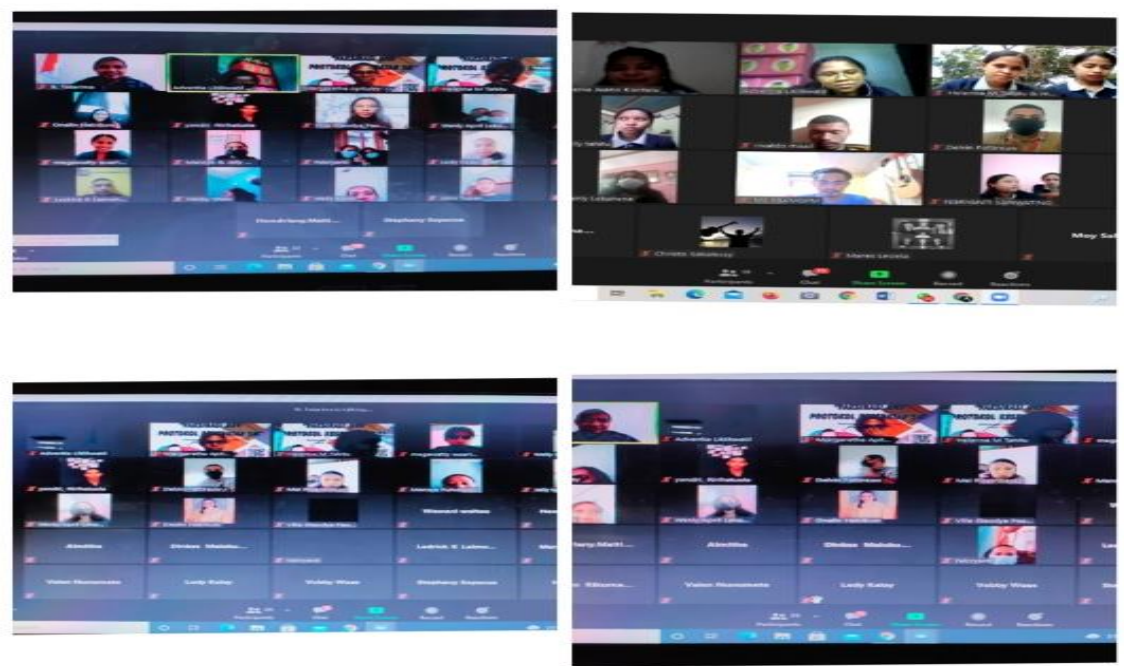

Gambar 1. sosialisasi vaksinasi dan prokes 


\section{- Pembagian Masker}

Pembagian Masker dilakukan dalam 2 kali kegiatan yang dilaksanakan pada tanggal 1 Agustus 2021 dan 5 Agustus 2021, kegiatan ini dilakukan sebagai kegiatan turunan dari sosiasialisasi vaksinasi dan protokol kesehatan $5 \mathrm{M}$ (Memakai masker,Mencuci tangan pakai sabun dan air mengalir,Menjaga jarak,Menjauhi kerumunan, serta Membatasi mobilisasi dan interaksi), dan dilakukan sebagai langkah efekteif untuk menyebarkan sosialisasi tidak langsung dalam Jemaat. Meski tidak mencakup dan diberikan secara simbolik kepada gereja dan para pengasuh tapi kami berharap bisa memacu kesdaran bermasker di tengah masyarakat.

Dari 22 pack masker yang ditargetkan 15 pack untuk Deswasa dan 7 pack untuk anak-anak semuanya tersalurkan = $100 \%$ berhasil. Jadi untuk luaran yang ditergetkan kelompok 100\% berhasil terlaksana.
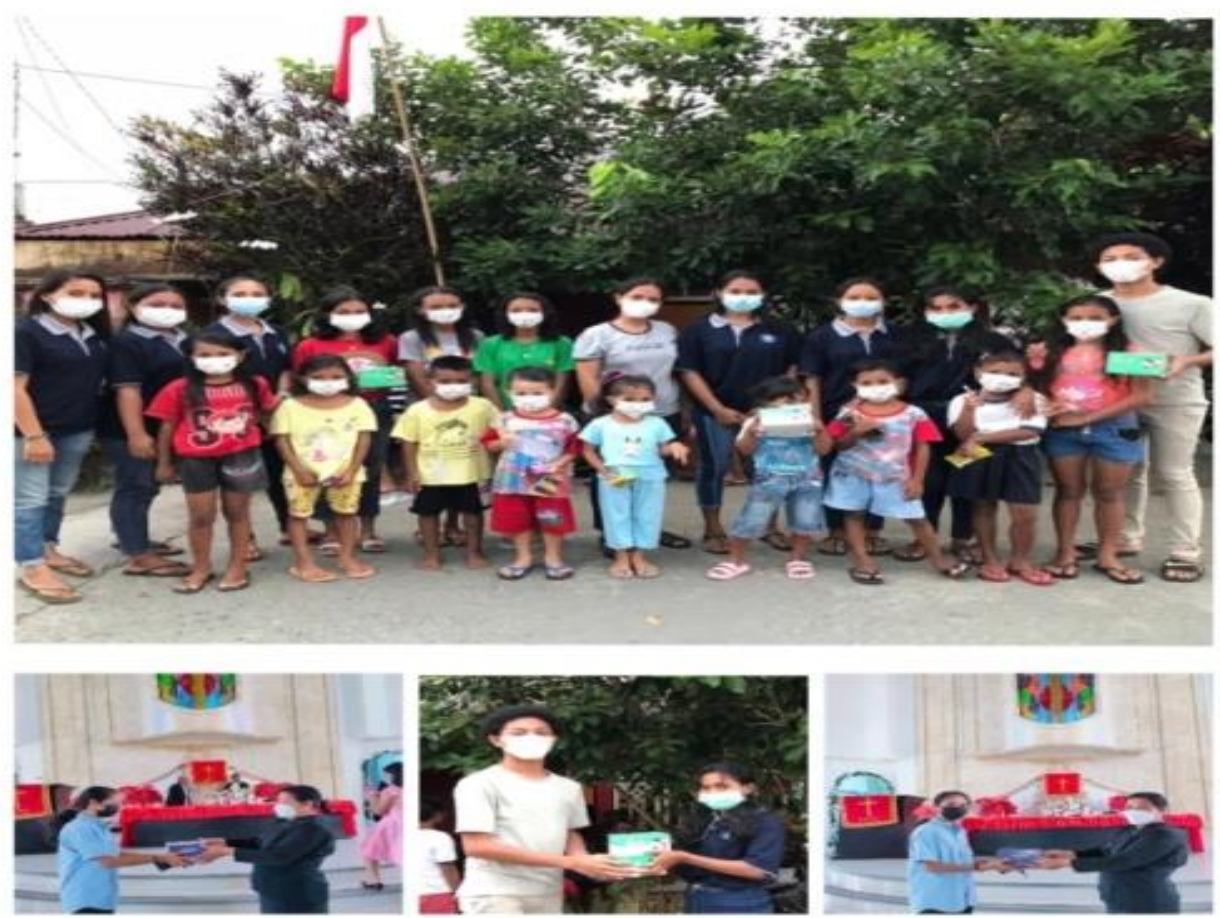

- Pemungutan Sampah

Gambar 2. Pembagian Masker

Dari 35 peserta yang di targetkan hanya 15 orang yang hadir atau sekitar $42,8 \%$ dari target dengan keberhasislan kebersihan lingkungan 50\% . jadi luaran kelompok dalam kegiatan ini ada 2 yang pertama dari jumlah peserta kehadiran dan tingkat keberhasilah kegiatan pembersihan 50\% dari 100\% yang ditergetkan

Pemungutan Sampah dilakukan pada 31 July 2021, kegiatan ini dilakukan karena menurut kelompok lingkungan yang kotor dapat memicu turunnya imun tubuh yang menyebakan orang lebih mudah terjangkit virus corona.Meskipun banyak kendala yang kami hadapi salah satunya adalah partisipan yang kurang dari yang ditargetkan atau yang diminta. Kerja bakti ini dilakukan bersama Kalesang Negri Waai dan AM Cabang Damai Waai. 


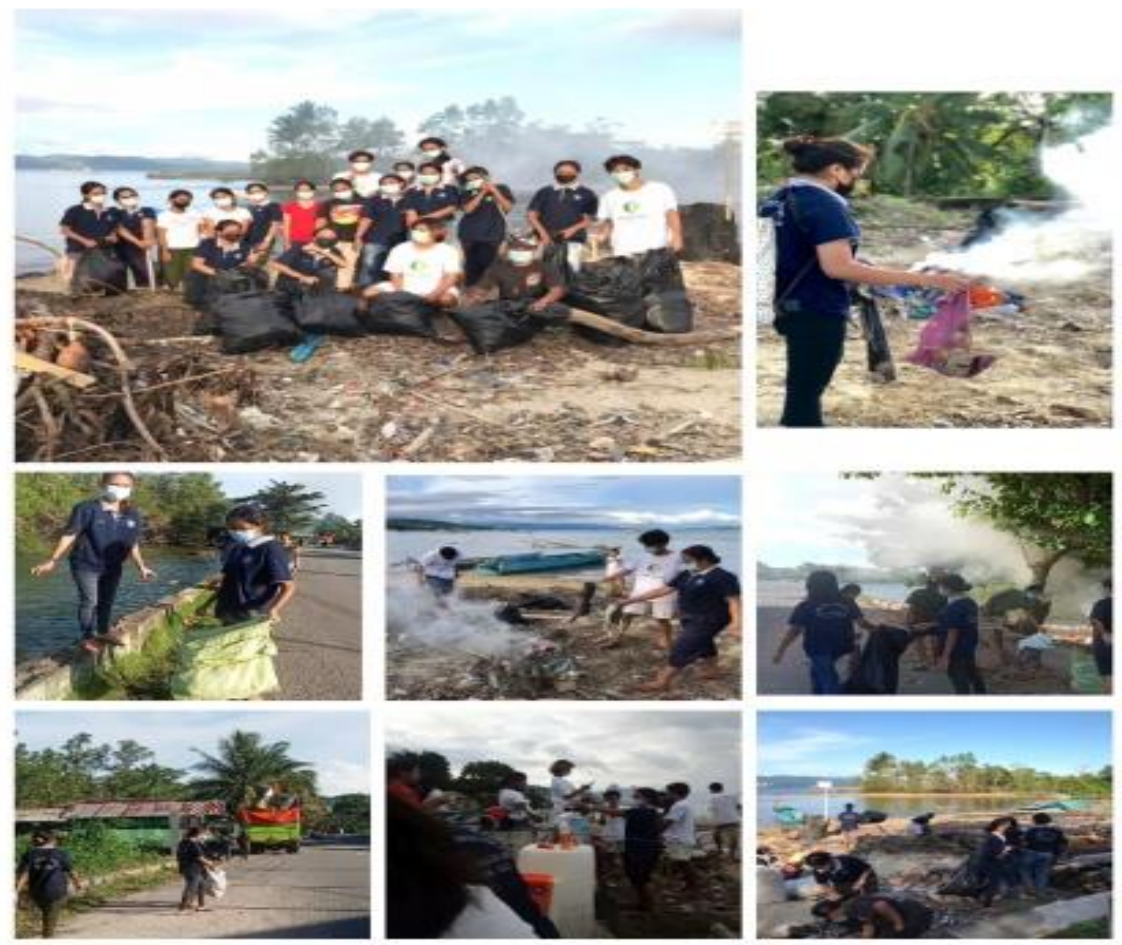

- Penyuluhan Sampah

Gambar 3 Pemungutan Sampah

Penyuluhan sampah dilakukan pada tanggal 3 Agustus 2021, pulul 14:00-16:00, dengan 2 narasumber yaitu ketua Beta Bank Sampah Dan Ketua Kalesang negri Waai dan dilakukan secara daring melalui media zoom, kegiatan ini berisikan pengetahuan bagaimana mengelola sampah menjadi barang bernilai dan shaering bagaimana seharunya pemuda bersikap dengan sampah di sekitar .kegitan ini dilakukan untuk menindaklanjuti kegiatan kerja bakti supaya mereka tidak hanya peduli sampah tetapi juga kreatif.

Kegiatan penyuluhann ini ditargetkan kepada pemuda AM Cabang damai Waai. Seperti sosialisasi sebelumnya, kegiatan penyuluhan ini ditargetkan dengan 100 peserta dari AM hanya sekitar 15 orang yang hadir yang artinya keberhasilan kegiatan ini hanya 15\% tingkat keberhasilannya.luaran dari penyuluah ini di ukur melalui google form yang dimana hanya sekitarn 8 orang yang mengisi dan rata-rataa jawaban bahwa kegiatan ini sangat berguna namun tidak mencakup semua target.

\section{- Pemberian Tempat Sampah}

Pemberian Tempat sampah dilakukan tanggal 17 Agustus 2021 kepada Gereja dan akan di letakan pada titik tertentu, seperti yang sudah dijelaskan kegiatan ini termasuk dalam kegiatan untuk menindaklanjuti kerja bakti yang dilakukan kelompok sebelumnya, selain itu kegiatan ini sebagai bentuk cendaa mata kelompok kepada jemaat di Waai. Dari 2 buah yang awalnya ditargetan menjadi 4 buah yang di berikan maka target luaran kelompok 100\% berhasil.

\section{- Pembuatn Video Kreatif}

Pembuatan Video Ini dilakukan untuk menjembatani sosialisasi yang telah terjadi seperti hal-Nya pembagian Masker, pembuatan Video dilakukan dan kegiatan lain yang luarannya sedikit dari target yang di hasilakan dengan tujuan mengedukasi masyarakat tentang vaksinasi dan Prokes $5 \mathrm{M}$, yang membedakan adalah video kreaatif mencakup lebih banyak. Dapat ditonton dalam channel Youtube : kelompok 8 KKN- Teologi UKIM 2021 


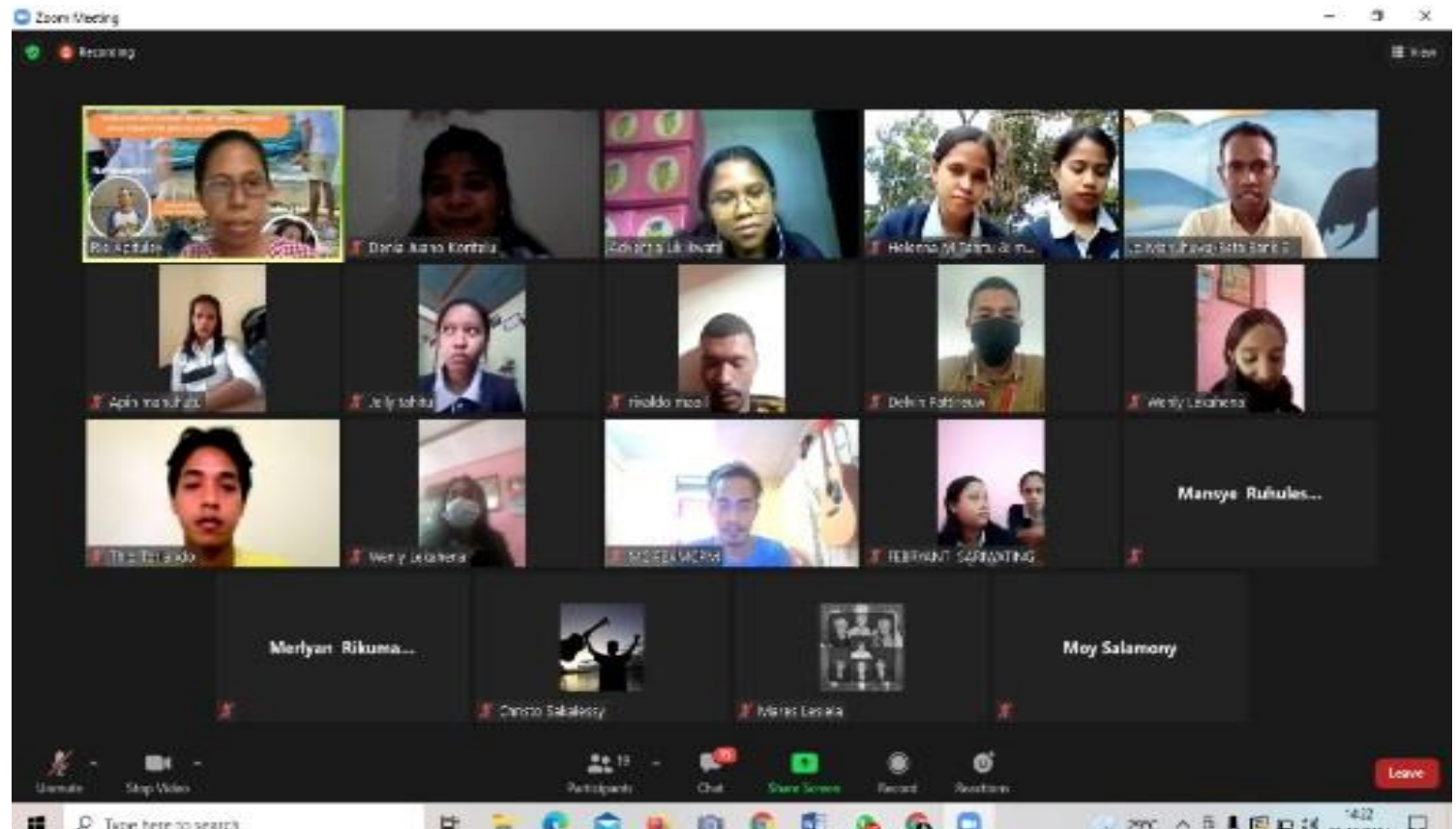

Gambar 4. Penyuluhan sampah
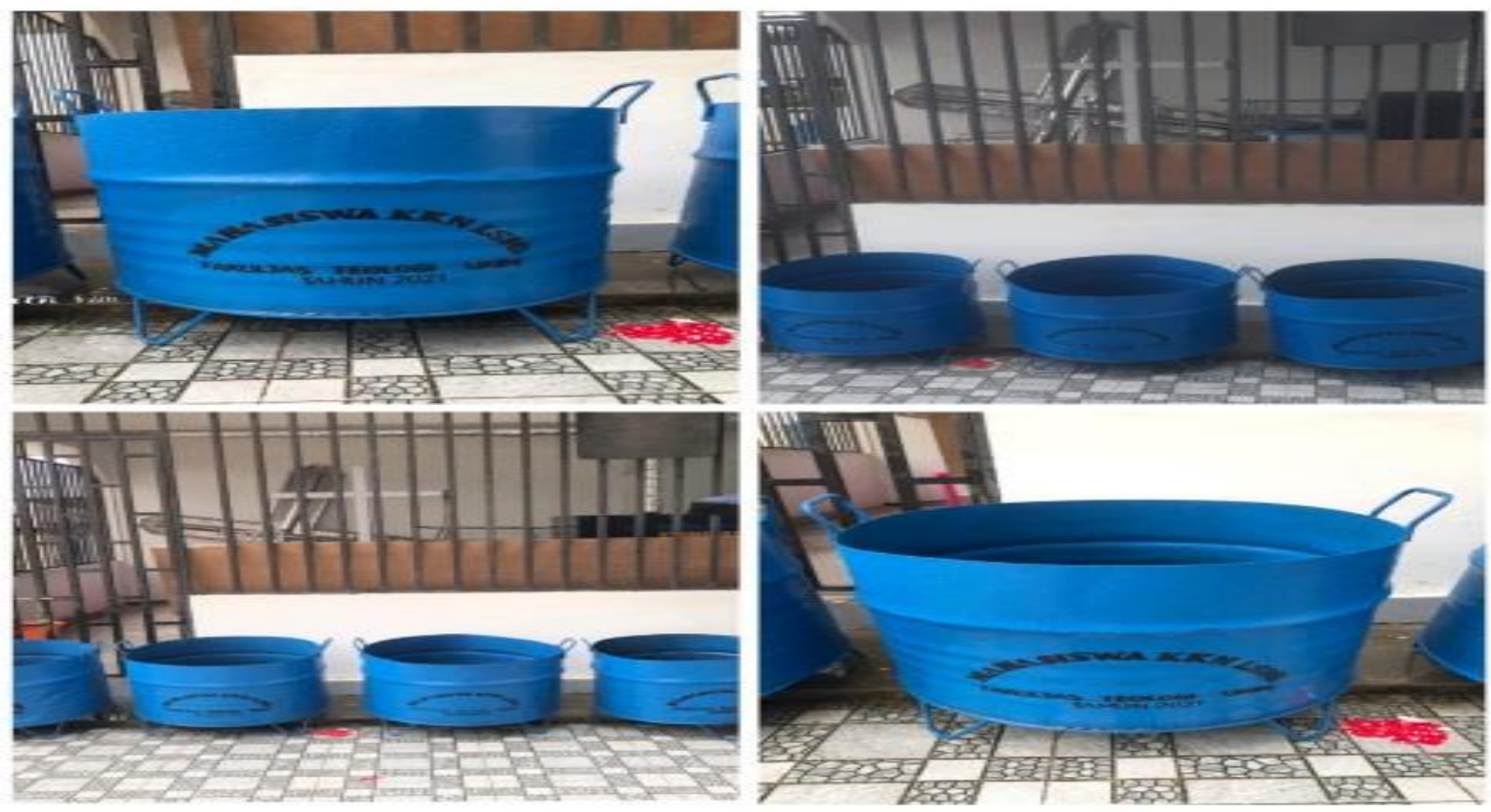

Gambar 5. Pembuatan sampah 

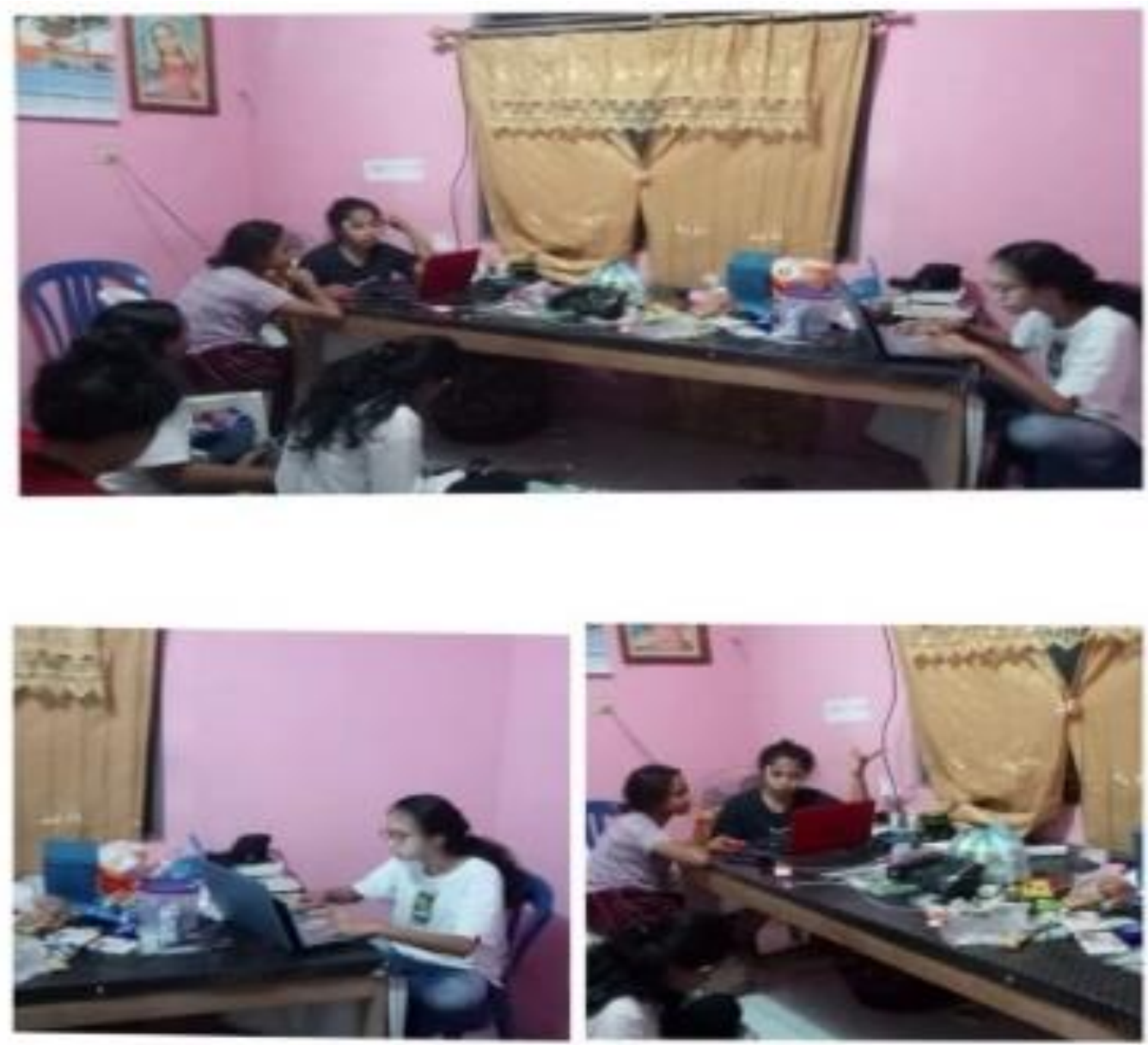

Gambar 6. Pembuatan Video Kreatif

\section{Kesimpulan}

Setiap program akan dilakukan baik secara online maupun offline dengan penerapan protokol Kesehatan, programprogram tersebut antara lain, sosialisasi vaksinasi dan protokol kesehatan 5M, Pembagian Masker dan Pembuatan Video Kreatif Vaksinasi dan beberapa kegiata lainnya sebagai pendukung. Semua kegiatan ini diharapkan untuk membantu dan membangun kesadaran Masyarakat untuk dapat mencegah Virus Corona ataupu menyelesaikan msalah yang ada dalam jemaat Waai. Kegiatan kelompok akan di khususkan pada jemaat Waai Kecamatan Salahutu, Kabupaten Maluku Tengah dan diharapkan edukasi tentang vaksinasi dan prokes 5M dapat lebih ditingkatkan sehingga semua masyarakat lebih banyak mengetahui dan mencegah penyebaran COVID 19.

\section{References}

Ahmar, A.S. \& Boj, E. (2020). The date predicted 200.000 cases of COVID-19 in Spain. Journal of Applied Science, Engineering, Technologi, and Education, 2(2), 188-193.

Ellyvon, P. (2021). Diumukan awal Maret, Ahli : Virus Corona Masuk Januari. Jakarta: Kompas.com. URL: https://www.kompas.com/sains/read/2020/05/11/130600623/diumumkan-awal-maret-ahli--virus-coronamasuk-indonesia-dari-januari/. Access: 30 July 2021. 
Apituley, et.al | Panrannuangku Jurnal Pengabdian Masyarakat, 2022, 2(1): 40-48

Pane, M. D. C. (2021). Virus Corona. URL: https://www.alodokter.com/virus-corona. Access: 15 August 2021.

Puskesmas Waai. (2021). Tenaga kesehatan Puskesmas Waai, Data Vaksinasi Dan COVID Negeri Waai sampai dengan 31 July 2021. Ambon: Puskesmas Waai.

Tim Renstra. 2020. Majelis Jemaat Waai. Renstra Jemaat GPM Waai, Ambon: BPHJ Jemaat Waai. 